Published in final edited form as:

Curr Pharm Des. 2015 ; 21(21): 3032-3040.

\title{
Inflammation Fuels Tumor Progress and Metastasis
}

\author{
Jingyi Liu ${ }^{1,2}$, Pengnian Charles Lin ${ }^{3}$, and Binhua P. Zhou ${ }^{2, *}$ \\ ${ }^{1}$ The State Key Laboratory of Experimental Hematology, Institute of Hematology and Blood \\ Diseases Hospital, Chinese Academy of Medical Sciences and Peking Union Medical College, \\ Tianjin 300020, China \\ 2Departments of Molecular and Cellular Biochemistry, and Markey Cancer Center, University of \\ Kentucky School of Medicine, Lexington, KY 40506 \\ ${ }^{3}$ Center for Cancer Research, National Cancer Institute-Frederick, Frederick, MD 21702, USA
}

\begin{abstract}
Inflammation is a beneficial response that can remove pathogens, repair injured tissue and restore homeostasis to damaged tissues and organs. However, increasing evidence indicate that chronic inflammation plays a pivotal role in tumor development, as well as progression, metastasis, and resistance to chemotherapy. We will review the current knowledge regarding the contribution of inflammation to epithelial mesenchymal transition. We will also provide some perspectives on the relationship between ER-stress signals and metabolism, and the role of these processes in the development of inflammation.
\end{abstract}

\section{Keywords}

Epithelial-mesenchymal transition; Inflammation; Metastasis

\begin{abstract}
A similarity between the chronic inflammatory processes associated with wound healing and tumor development was noticed by Rudolf Virchow more than 150 years ago, as both processes present with significant leukocyte infiltration [1]. An inflammatory niche, containing stromal fibroblasts, endothelial cells, infiltrated lymphocytes and secreted cytokines, chemokines and growth factors is not only essential for the normal wound healing process but also contributes significantly to the development and progression of cancer. Here, we discuss recent discoveries on the inter-relationships of inflammation, epithelialmesenchymal transition (EMT), endoplasmic reticulum (ER) stress and metabolism, which collectively contribute to oncogenesis.
\end{abstract}

\section{Tight Relationship between Chronic Inflammation and Cancer Development and Metastasis}

Wound healing and tumor development share many similarities in regulatory processes, signaling pathways, and gene expression profiles. Both events involve cell survival,

*Corresponding Author: Binhua P. Zhou, Department of Molecular and Cellular Biochemistry, 741 South Limestone Street, Lexington, KY 40536, Tel.: 859-323-4474, peter.zhou@uky.edu. 
migration, and proliferation, and are controlled by numerous secretary factors, including growth factors, cytokines and chemokines, from the microenvironment of the wound or cancer. The similarities of these two events led Dvorak to postulate that cancer is a "wound that never heals" [2]. Indeed, daily irradiation under sun, chronically exposure to cigarette smoke or other environmental carcinogens in lung, and constant viral or bacterial infection in stomach, liver, and cervix produce chronic tissue injury and subsequent oncogenesis in these organs [3]. Many epidemiologic and clinical studies also show that approximately $25 \%$ of all solid tumors result from chronic inflammation [4], and that the consumption of antiinflammatory agents (such as non-steroidal anti-inflammatory drugs) positively correlates with a reduced incidence of colorectal, breast, pancreatic, and gastric cancers [5]. During wound healing, the major function of inflammation is to destroy pathogens and infectious agents, to activate the immune system by eliciting innate and acquired immune responses, and to remodel injured tissues. This acute inflammation is a fast self-contained event; the signals and regulatory machinery that normally initiate and sustain the processes terminate when healing is complete. However, in cancer, inflammation becomes a persistent process, with a "failure to heal" lesions. Chronic inflammation and the subsequent persistent tissue injury, lead to changes in epithelial cytoarchitecture and surrounding stromal components, and enhance genetic mutations and epigenetic aberrations of epithelia cells. This alteration in tissue homeostasis causes a feed-forward chronic inflammatory response that never fades away, promoting tumor proliferation, angiogenesis, invasion, and metastasis through activation of surrounding stromal cells and recruitment of immune cells. Inflammation has been recognized as a "hallmark of cancer" $[6,7]$. The fundamental mechanisms responsible for chronic inflammation in tumors remain elusive and many outstanding questions remain to be addressed; for instance, how does chronic inflammation enhance tumor cells resistant to apoptosis, invade to adjacent tissues, and metastasize to distant organs? Here we summarize recent findings from our laboratory and studies obtained by others that focus on the mechanisms and signaling pathways underlying inflammation-mediated metastasis.

\section{Inflammation and EMT}

\section{(a) Overview of EMT}

The concept of EMT was first proposed in 1967 by Elizabeth Hay from a seminal observation on chicken embryo development [8]. EMT is a phenotypic conversion during embryonic development with tissue remodeling and cell migration that shape the future organism; the same processes occurs during wound healing. Pathologically, a similar EMT process ensues for fibrotic diseases and during metastasis. During EMT, epithelial cells lose the expression of adherens and tight junction molecules that hold cells together; they change to a mesenchymal morphology and gain the ability to break basal membranes and invade to adjacent tissue or distant organs [9]. EMT is divided into three subtypes based on different biological conditions [10-12]. Type 1 EMT describes a constellation of events in which epithelial cells become motile mesenchymal cells during gastrulation, mesoderm formation, and neural crest delamination. These primary mesenchymal cells can revert, and form secondary epithelia in mesodermal and endodermal organs through mesenchymal-epithelial transition (MET). Type 2 EMT involves the program of generating tissue fibroblasts from epithelial or endothelial cells during wound healing and tissue remodeling. This type of 
EMT will eventually lead to tissue fibrosis and organ malfunction if inflammation becomes chronic. Type 3 EMT describes how tumor cells undergo a phenotypic transition in order to detach, invade, and metastasize through the blood or lymphatic systems and form a metastatic lesion through MET at distant sites [13]. Despite this classification, the genetic elements and regulatory mechanisms among three subtypes of EMT are likely similar and well conserved. For example, E-cadherin is a cell-cell adhesion molecule that is required to form epithelial adherent junctions in a homotypic, calcium-dependent mechanism $[14,15]$. The cytoplasmic tail of E-cadherin binds to $\alpha$ - and $\beta$-catenin to modulate cytoskeleton and gene expression during cell-cell adhesion and cell migration. Loss of E-cadherin disrupts the cell-cell adhesion and alters gene expression by increasing $\beta$-catenin nuclear localization $[14,15]$. Loss of E-cadherin expression is an important hallmark of EMT and is often correlated with the tumor grade and poor patient survival. In contrast, $\mathrm{N}$-cadherin, which is highly expressed in mesenchymal cells, fibroblasts, neural tissue, and cancer cells, is elevated during EMT. This cadherin switch, from E-cadherin to N-cadherin, is closely associated with invasiveness, motility and metastasis of tumor cells. Quite interesting, this switch of gene expression pattern is also noted in discoidin domain receptor (DDR) family and integrin members. DDR1 is highly expressed in epithelial cells whereas DDR2 is mainly expressed in mesenchymal cells. DDR1 expression is switched to DDR2 during EMT. In addition, integrins modulate the interaction of cells with the extracellular matrix (ECM), a $3 \beta 1$ integrin is a laminin-binding receptor whereas a $5 \beta 1$ integrin is a receptor for fibronectin. Expression of a 3 is downregulated whereas a 5 expression is elevated in EMT [16-18].

\section{(b) Distinct but Complementary Roles of Snail and Twist in EMT}

EMT is orchestrated by a network of EMT-transcription factors (EMT-TFs), including Snail/ Slug, Twist1, ZEB1/ZEB2, E12/E47, Goosecoid, and SIP1 [19-21]. These factors act as a molecular switch to induce the EMT program by repressing a subset of adherens and tight junction molecules (such as cadherins, claudins, integrins, mucins, plakophilin, occludin and ZO1) and by activating expression of genes that can facilitate cell migration and invasion. Snail is zinc-finger transcription factor that plays an evolutionary conserved role in mesoderm formation from vertebrates to human [20]. First identified in Drosophila melanogaster, Snail represses expression of neurocetodermal genes such as single-minded and shotgun, which are essential for the formation of the mesoderm and neural crest [22]. In Drosophila, Snail inhibits E-cadherin expression, promotes cadherin endocytosis, and this is essential for the delamination and ingression of primary mesenchymal cells [23]. Snail is critical for gastrulation and normal development in mice [24]. Mice with homozygous knockout of Snail died at embryonic stage due to failure of mesoderm formation, which prevents gastrulation. Human Snail resides in chromosome 20q13, a region that is commonly amplified in breast cancer. The carboxyl-terminal region of Snail family members contains 4-6 C2H2-type zinc fingers, which specifically bind to DNA promoters containing an E-box sequence (CAGGTG). The N-terminus of all vertebrate Snail family members possesses a highly evolutionarily conserved SNAG (Snail/Gfi) domain, which is required for the transcriptional repressive activity of Snail (Figure 1). Snail directly recruits three key chromatin-modifying enzymes (LSD1, G9a and Suv39H1) through the SNAG domain to silence the E-cadherin promoter [25-27]. We also discovered that this Snail 
repressor complex suppresses the expression of fructose-1.6-biphosphatase (FBP1) and induces aerobic glycolysis and cancer stem cell (CSC)-like properties during tumor development and metastasis [28]. In addition, Snail was found to interact with the corepressor complex SIN3A and HDAC1/2 to alter the chromatin structures for E-cadherin silencing [29].

Snail is a highly labile protein; we discovered that Snail is regulated by both protein stability (ubiquitination) and cellular location (phosphorylation) [30]. The repressive functions of Snail require residence in the nucleus; cytoplasmic Snail has a very short half-life and is targeted for ubiquitin-mediated proteasome degradation through GSK-3 $\beta$-mediated phosphorylation. We identified and characterized the kinase (GSK-3 $\beta$ ) [30], phosphatase (SCP1) [31], and ubiquitin E3 ligase ( $\beta$-Trcp) [30] that govern Snail regulation. In addition, the p21-activated kinase 1 (PAK1) can also modulate the subcellular localization of Snail; Pak1 phosphorylates Snail at S246 and promotes the nuclear translocation of Snail in EMT [32]. In addition to $\beta$-Trcp (FBXW1), several E3 ligases, FBXL14 (Ppa), FBXL5, and FBXO11, have been shown to regulate the protein stability of Snail under different cellular contexts.

On the other hand, Twist belongs to the family of transcription factors that contain basic helix-loop-helix (bHLH) domain (Figure 1). Many studies indicate that Twist is required for EMT and the acquisition of CSC-like properties; cells with abundant Twist expression have the $\mathrm{CD} 44^{+} \mathrm{CD} 24^{-}$phenotype and self-renewal ability [33-35]. Twist-induced EMT is well known to contribute to tumor cell invasion and metastasis by activating several signaling pathways such as Mir-10b and PDGFR [21, 36, 37]. It has also been reported that Twist plays an important role in the inhibition of oncogene-induced senescence and acquisition of chemotherapeutic resistance [38-42]. Twist is also subjected to post-translational modifications and degradation. Two residues, Thr125 and Ser127, at the C-terminal of the bHLH domain are phosphorylated by protein kinase A (PKA) [43]. PKB/AKT allows the Ser42 phosphorylated Twist to confer resistance to p53-mediated apoptosis in response to DNA damage, and promotes EMT and metastasis in breast cancer by enhancing TGF- $\beta$ signaling $[44,45]$. Three mitogen-activated protein kinases, p38, c-Jun $\mathrm{N}$-terminal kinases (JNK), and extracellular signal-regulated kinases1/2 were reported to phosphorylate Twist at serine 68 in vitro and prevent its protein degradation as well as promote breast cancer cell invasion [46]. Interleukin 6 (IL-6) activates casein kinase 2, which phosphorylates Twist at Ser 18 and Ser 20, leading to Twist stabilization and increased cancer cell motility [47]. Recent studies also show that the stability of Twist is negatively regulated by GSK-3 $\beta$ mediated phosphorylation on the WR motif (also known as the Twist box) of Twist protein [48].

The C-terminal bHLH domain of Twist recognizes the DNA sequence known as the E-box motif. Many mutations which cause Saethre-Chotzen syndrome are located within the bHLH domain demonstrating its functional importance [49]. The WR motif resides on the cterminus of bHLH domain. Several molecules were reported to associate with the WR domain of Twist, and several point mutations in the WR domain are also linked to SaethreChotzen syndrome [50-52]. By using unbiased protein purification coupled with mass spectrometry analysis, we identified that Twist is di-acetylated at Lys73 and Lys76 [53]. 
This di-acetylation creates the "histone H4-mimic" GK-X-GK motif that is essentially for the interaction with the second bromodomain of BRD4 and the recruitment of BRD4/ pTEFb/RNA-PolII complex to the promoter and superenhancer of Twist target genes; these events lead to the transcription activation of downstream signaling program.

Although Twist has been shown to bind to the E-cadherin promoter and repress its transcription in a manner similar to that of Snail, our studies indicate that Snail and Twist have distinct yet complementary functions in EMT regulation by functioning as a repressor and activator, respectively. Snail functions as a transcriptional repressor to suppress genes that prevent cell migration and growth (such as E-cadherin and FBP1); whereas Twist acts as a transcriptional activator to induce genes that favor cell migration and proliferation (such as Wnt5A). An analogy would be a moving car that has disabled brakes and an accelerating engine (Figure 1). Our results are supported by the findings seen during mesoderm formation in Drosophila, in which Snail functions as a transcriptional repressor to prevent ectoderm gene expression; whereas Twist serves as a transcriptional activator to induce mesodermal gene expression. Snail and Twist work synergistically, controlling distinct sets of genes, to coordinate EMT and mesoderm formation.

\section{(c) EMT Occurs at the Tumor Invasive Front and is Driven by an Inflammatory Tumor Microenvironment}

EMT is a reversible and dynamic event that is initiated and propelled by microenvironmental signals that cells received. In line with this contention, EMT is commonly observed at the tumor-stromal boundary of many invasive tumors $[54,55]$. The tumor microenvironment evolves as tumor develops; this includes fibroblasts, endothelial cells and infiltrated immune cells (such as neutrophils, myeloid-derived suppressor cells (MDSC), as well as extracellular matrix $(\mathrm{ECM})$ proteins, such as collagen, hyaluronic acid and fibronectin. Oncogenic signaling within tumors frequently drives the recruitment of normal fibroblasts (NAFs) and reprograms them into cancer associated fibroblasts (CAFs) [56]. CAFs are activated fibroblasts that share similarities with fibroblasts and are stimulated by inflammatory conditions or activated during wound healing [57]. In the tumor microenvironment, CAFs and the infiltrated immune cells secrete growth factors, such as fibroblast growth factor (FGF), epidermal growth factor (EGF), and hepatocyte growth factor (HGF), cytokines (Il-1 $\beta$, IL-6, and IL-8), and chemokines (CXCL12, CXCL14 and CCL7) that all together play an essential role in promoting tumor proliferation and facilitating metastasis [58]. A high content of inflammatory cells, particularly tumor-associated macrophages (TAM), are commonly observed at the invasive fronts of advanced carcinomas and correlate with increased metastasis [59]. TAMs are a key component of infiltrated immune cells in tumor stroma, they play an important role in chronic inflammation and have been viewed as an "obligate partner for tumor-cell migration, invasion and metastasis" [59]. TAMs modulate inflammation and adaptive immunity, increase tumor growth, enhance angiogenesis, and promote tissue remodeling and fibrosis. Patient samples from different solid tumors show a strong correlation of TAM content in tumor with a poor clinical outcome [60]. Intriguingly, TAMs often cluster around blood vessels and the tumor margin and produce a variety of proteases to facilitating ECM remodeling, basement membrane degradation, and tumor cell 
invasion. In fact, metalloproteinase 9 (MMP9) and urokinase-type plasminogen activator (uPA) are produced mainly from TAMs.

CAFs constitute another significant component of the tumor stroma and mediate changes in extracellular matrix composition to one with increased amounts of collagens (desmoplastic response) [61, 62]. CAFs are activated fibroblasts that share similarities with fibroblasts and are stimulated by inflammatory conditions or activated during wound healing [57]. Hypoxia and ROS can also promote activation of CAFs. CAFs are phenotypically and functionally distinct from NAFs and can be identified based on the expression of several markers including a-SMA, FAP, FSP1, and PDGFR. TGF- $\beta$, PDGF, bFGF, IL-6, and LPA, which can induce desmoplastic reactions in tumors, also stimulate the differentiation and proliferation of NAFs to CAFs. Distinct from NAFs, CAFs significantly promote tumor growth in xenograft models when mixed with tumor cells. The tumor-promoting effects of CAFs are mainly mediated through a paracrine mechanism involving multiple secreted factors, including HGF, CTGF, EGF, IGF, NGF, bFGF, Wnt ligands, and MMP. In addition to these paracrine events, CAFs secrete many chemokines. For instance, CAFs secrete CXCL12, which binds and activates CXCR4 in tumor cells, to induce migration and proliferation of tumor cells [63]. In addition, CAFs can change their metabolic profile and provide metabolic intermediates necessary for the growth of tumor cells [64]. We showed recently that downregulation of isocitrate dehydrogenase $3 a$ (IDH3a) plays a critical role in the metabolic reprogramming in CAFs [65]. Downregulation of IDH3a decreases the effective level of $\mathrm{a}-\mathrm{KG}$ by reducing the ratio of $\mathrm{a}-\mathrm{KG}$ to fumurate and succinate; this event results in PHD2 inhibition and HIF1a protein stabilization. The accumulation of HIF1a, in turn, promotes glycolysis by increasing the uptake of glucose, upregulating expression of glycolytic enzymes under normoxic conditions, and inhibiting oxidative phosphorylation by up-regulating NDUFA4L2. CAF from tumor samples exhibit low levels of IDH3a, and overexpression of IDH3a prevents transformation of fibroblasts into CAFs. Together, these findings reveal IDH3a is a critical metabolic switch in CAFs.

Myeloid-derived suppressor cells (MDSC) are also present in many cancer patients and animals with xenografted or naturally developed tumors $[66,67]$. MDSCs, characterized by $\mathrm{CD} 11 \mathrm{~b}^{+} \mathrm{Gr}-1^{+}$in mice, are recruited and activated by several inflammatory factors, such as IL-1 $\beta$, IL-6, and VEGF [68]. MDSCs also produce pro-inflammatory factors to further amplify the inflammatory response in tumor stroma. MDSCs crosstalk with macrophages to impair the activation of CD4(+) and CD8(+) T cells [69]. In Tgfbr2-decificent mice, MDSCs are recruited to the tumor invasive front through chemokine receptors CXCR2 and CXCR4, and thus enhance tumor cell invasion and dissemination [70]. A high level of MDSCs correlates with tumor grade, staging, metastatic tumor burden, and drug resistance in patients [71].

In addition to the stromal cells discussed above, lymphocytes, neutrophils, mast cells, Tregulatory cells and platelets, also contribute to the development of tumor microenvironment and, foster the growth, and facilitate the invasion and metastasis of tumor cells. 


\section{(d) EMT Generates Cancer Stem Cells}

Epithelial-mesenchymal Transition (EMT) is a de-differentiation program that imparts tumor cells with the phenotypic and cellular plasticity required for metastasis, drug resistance, and disease recurrence. Morphologically, EMT confers tumor cells with fibroblast-like properties that result in reduced intercellular adhesion and increased motility. Functionally, EMT endows tumor cells with CSC-like traits and renders them resistant to therapeutics, with a proclivity for recurrence after treatment [33, 72-74]. Consistent with this notion, circulating tumor cells (CTCs), isolated from the blood of breast cancer patients, are enriched in EMT and CSC markers [75-83]. During development, part of the epithelial cells in ectoderm give rise to mesoderm through EMT, and these cells can further differentiate into different cell lineages and generate various organs, such as muscle, bone, and connective tissues. Through EMT, neural crest cells can also delaminate from neural crest and give gives rise to glial and neuronal cells, adrenal glandular tissues, pigment-containing cells of the epidermis and skeletal and connective tissues. These observations indicate that EMT is a cellular differentiate/de-differentiate program utilized during embryonic development and tissue remodeling and that tumor cells hijack this program for their own benefit for generating CSC-like properties during metastasis. Intriguingly, basal-like breast cancer (BLBC), which is a subtype of breast cancer that associates with distant metastases, disease recurrence and short survival times [84-88], is enriched with EMT characteristics and CSC-like traits. This subtype of breast cancer contains high percentage of CSC cells that possess $\mathrm{CD} 44^{+} / \mathrm{CD} 24^{-}$expression; these cells display E-cadherin downregulation and fibronectin and vimentin upregulation, and they also contain high levels of EMT-TF expression, such as Snail, Slug, Twist, and FOXC2. Mani et al showed that EMT can endow tumor cells with CSC-like traits [33, 89]. Expression of Snail or Twist in immortalized mammary epithelial cells increases tumorsphere-formation, a phenotypic characteristic associated with stem cells. In addition, TGF $\beta$ not only induces EMT but also increases the population of CSC-like cells $\left(\mathrm{CD} 44^{+} / \mathrm{CD} 24^{-}\right)$in breast cancer, suggesting that tumor microenvironment contributes greatly to promote metastasis by propelling EMT. Clinically, breast tumor samples from patients developed resistance to chemo- and endocrine therapies are enriched with cells containing CSC characteristics and EMT markers. Interestingly, a distinct population of highly invasive pancreatic stem cells display the expression of both $\mathrm{CD}_{133^{+}}$and CXCR4 at the invading edge for tumor [90]. The observations that EMT occurs at the tumor invasive front and that EMT provides tumor cells with "metastatic cancer stem cell" traits underscores the contention that EMT is critical for tumor progression and metastasis. In line with this contention, several developmental pathways (such as Wnt, Hh and Notch) that control self-renewal and differentiation of stem cells also involve in EMT induction. Therefore, EMT confers tumor cells with invasive power for metastatic dissemination at the primary tumor, and the CSC-like properties needed for colonization and proliferation of metastatic lesion.

\section{Hypoxia and Inflammation}

A hypoxic condition, in which the level of $\mathrm{O}_{2}$ pressure is below $10 \mathrm{mmHg}$, is commonly found in many human solid tumors. Cells respond to hypoxia by stabilizing HIF1a that, in turn, heterodimerizes with HIF1 $\beta$ and induces the transcription of numerous target genes 
involve in angiogenesis, glucose metabolism, survival and metastasis. For example, HIF1a induces VEGF to promote angiogenesis. HIF1a also increases CXCR4 expression in renal cell carcinoma to promote organ specific metastatic dissemination [91]. The crosstalk between hypoxia and EMT was identified recently, HIF1a regulates the expression of several EMT-TFs, such as Snail, Slug, Twist, ZEB1 and SIP1, directly or indirectly, and thus promotes EMT induction and increases metastasis under hypoxia [92-96]. Interestingly, the level of HIF1a correlates with Snail and Twist expression; co-expression of these proteins predicts the highest probability of metastasis and correlates with the worst prognosis in head and neck cancer [96]. Expression of uPA, it's receptor (uPAR), MMP-2 and MMP-9 are also increased under hypoxia, and their expression promote invasion and metastasis both in vitro and in vivo [97]. In addition, expression of LOX, which can stabilize Snail and promote its activity $[98,99]$, is also increased under hypoxia. LOX promotes the remodeling of tumor microenvironment by facilitating the maturation of newly synthesized collagen fibrils, and thus increases invasion and metastasis through enhancing the focal adhesion kinase activity in tumor cells. The interaction of Snail with LOX highlights a synergistic effect on EMT induction under hypoxia. The cross-talk among pathways involved in inflammation, hypoxia and EMT in vivo is an interesting area that requires further investigated.

\section{ER Stress Signals Contribute to Chronic inflammation in Tumor Development}

The main purpose of an inflammatory response is to remove a foreign agent disturbing tissue homeostasis. In the normal physiological context, inflammation is terminated and the homeostatic state recovered after tissue repair or pathogen elimination. It is now widely accepted that inadequately resolved chronic inflammation promotes the development of cancer. Although a constant presence of antigens are found in some types of inflammationassociated cancers, such as hepatitis antigen in liver cancer and HPV antigen in cervical cancer, most tumors that have chronic inflammation with no noted antigens. The mechanisms by which these tumors maintain constant inflammation remains an enigma. Emerging evidence suggest that ER stress signaling represents a fundamental mechanism of chronic inflammation. All newly synthesized secretory and membrane-bound proteins, the molecules a cell uses to communicate with the outside world, are glycosylated, properly folded, and assembled in the lumen of endoplasmic reticulum (ER). Cells sense environmental stresses by increasing protein unfolding in ER, and develop three parallel branches of the sensing mechanism, collectively named as the "unfolded-protein response" (UPR), to cope with stress [100-103]. The first branch is the activation of transcription factor 6 (ATF6), which migrates to the Golgi apparatus upon activation. There, ATF6 undergoes intramembrane proteolytic cleavage, which liberates the soluble N-terminal basiczipper-containing cytoplasmic domain of ATF6. This ATF6 fragment subsequently migrates to the nucleus to induce robust expression of heat-shock proteins needed to enhance the folding ability of the ER. The second branch requires PKR-like ER kinase (PERK) that undergoes oligomerization and autophosphorylation when cells under ER stress. Activated PERK phosphorylates the a-subunit of eukaryotic translation-initiating factor EIF2a; the phosphorylated EIF2a causes a global translational repression to reduce the overload on ER, and concurrently increases transcription factor ATF4 for heat-shock protein production. 
The ATF6 and PERK branches appear in metazoan cells later in evolution; however, IRE1/ XBP1 represents the sole UPR-signaling branch conserved from yeast to metazoans including humans. IRE1 is an ER-bound kinase and a ribonuclease that promotes posttranscriptional maturation of XBP1 mRNA. When cells receive ER stresses, IRE1 triggers an unusual processing of the XBP1 mRNA, in which a 26 nucleotide intron-like region of mRNA is spliced out, resulting in a reading-frame shift of XBP1 mRNA. This truncated mRNA encodes a matured XBP1 (XBP1s) that contains an active transactivation domain at its $\mathrm{C}$-terminus. Using a genome-wide promoter binding assay, XBP1 was found to regulate a broad array of genes involved in ER function and physiology, cell differentiation, and DNA repair [104].

UPR monitors cellular stresses by inducing transcription of genes (e.g., heat-shock proteins) that increase folding capacity, with a reduction in the sensitivity of cells to inflammation [105]. When stress is extensive and devastating, this process serves as a cytoprotective function by executing an apoptotic program for killing rogue cells without causing chaos in the organism. Thus, UPR functions as a checkpoint to mitigate stresses and ensure cellular homeostasis. If UPR is disabled due to the loss of XBP1, an extended and "unresolved ER stress" results, with a chronic inflammatory response and metabolic changes [106]. An unresolved ER stress leads to the activation of the upstream kinase IRE1 that recruits TRAF2 for activation of NF- $\kappa \mathrm{B}$ and JNK pathways and proinflammatory gene expression [106-110]. For example, when $C$. elegans larvae are infected by $P$. aeruginosa, it activates the immune response mediated by p38 MAPK family member 1 (PMK-1) as well as the IRE1/XBP1-mediated stress response [111, 112]. Activation of XBP1 inhibits the harmful effect of PMK-1 activation in response to immune attack and reduces the sensitivity of larvae to infection-mediated inflammation. Loss of XBP1 resulted in larval lethality due to hyperactivation of PMK-1, and conversely, the knockdown of PMK-1 rescued this lethality. In addition, the intestinal epithelial cells of $\mathrm{XBP}^{-/-}$mice show spontaneous enteritis exemplified by crypt abscesses and large amount of infiltrated immune cells. These mice are highly susceptible to dextran sulfate sodium-induced colitis than their wild-type counterparts $[106,109,113]$. The intestinal epithelium of $\mathrm{XBP}^{-/-}$mice possess an elevated inflammatory response indicated by increased secretion of cytokines and chemokines. In addition, cultured $\mathrm{XBP}^{-/-}$intestinal epithelial cells showed a sensitive inflammatory responses to TNFa stimulation. All of these pathological changes are similar to the alterations seen in human inflammatory bowel disease (IBD). Consistent with this notion, XBP1 mutations were associated with IBD, Crohn's disease, and ulcerative colitis [102]. Together, these genetic and pathological observations indicate that XBP1 plays a conserved and critical role in reducing sensitivity to inflammation through its ability to remove stress and restore cellular homeostasis.

Similar to the phenomenon of IBD seen in $\mathrm{XBP}^{-/-}$mice, BLBC also harbors abundant infiltrating immune cells in comparison with other breast cancer subtypes[114-117]. In addition, BLBC cells have intrinsic NF- $\kappa B$ activation [118-122]. Using multiple analyses, we identified that XBP1 expression is greatly reduced in cells from human BLBC tumor samples and mouse breast cancer tissues. Loss of XBP1 expression due to Snail-mediated repression is associated with NF- $\mathrm{KB}$ activation and the enhanced CCL2 expression in BLBC cells. Based on these analyses, we speculate that loss of XBP1 results in "unresolved ER 
stress", which signals endogenous tissue injury and activates NF- $\kappa B$ pathway for the induction of CCL2. This "inside out" signal subsequently recruits TAMs and lymphocytes to generate an inflammatory/wound microenvironment [123-125], which in turn provides additional cytokines and growth factors to further boost EMT and foster CSC-like traits in a vicious cycle when continuously unchecked.

\section{Metabolism and Inflammation in Cancer Development}

Unlike normal tissue, cellular proliferation in tumors is an uncontrolled process. When the size of a tumor reaches the oxygen and nutrient diffusion limit, tumor cells encounter not only a profound metabolic challenge, but also hypoxia and nutrient deprivation. To survive in this hostile environment, tumor cells reprogram their intrinsic metabolic machinery to cope with these challenges and thus modulate the inflammation and immune response of the body. Cancer-associated cachexia (CAC), characterized by progressive loss of skeletal muscle mass, anorexia, anemia, lipolysis, and insulin resistance, is the most important tumor-associated systemic syndrome that causes approximately $15 \%-20 \%$ of cancer death. Many lines of evidence indicate that the excess of cytokines released from tumors (IL-6, $\mathrm{TNFa}$, IL-1, and IFN $\gamma$ ), trigger a systemic inflammation, leading to increased energy expenditure in patients. In advanced stages of cancer, IL-1 $\beta$ is more strongly associated with the clinical features of cachexia such as general weakness, loss of appetite, weight loss, and sarcopenia than other cytokines [126]. Increased IL-6 in a murine colon cancer correlates with the development of cachexia, whereas treatment with monoclonal antibody to murine IL-6 suppressed it [127]. In experimental CAC models, administration of the cytokines listed above led to anorexia, weight loss, acute-phase protein response, protein and fat breakdown, and increased levels of cortisol and glucagon, as well as decreased the level of insulin. All these together result in insulin resistance, anemia, fever, and elevated energy expenditure [128]. Although the mechanistic interaction between systemic inflammation and tumor development in patients has not yet been fully elucidated, it seems possible that a set of cytokines has to work in concert to induce $\mathrm{CAC}$ and that a single factor might therefore be poorly predictive of CAC.

$1,25(\mathrm{OH})_{2} \mathrm{D}$ is an active form of vitamin $\mathrm{D}$, which regulates calcium metabolism and bone strength. In addition, vitamin D binds its vitamin D receptor (VDR) in the nucleus to modulate gene expression, this results in numerous cellular effects in differentiation, antiproliferation, and anti-microbial, anti-inflammatory, and immunomodulatory functions in different tissues and organs [129-131]. Several metabolic active tissues, such as kidneys, bone, and intestine, contain highest VDR expression, whereas the vast majority of other human tissues show low to moderate level of VDR. The $V d r$ gene resides on chromosome 12q13.11; several nucleotide polymorphisms of $V d r$ gene have been reported in close correlation with the severity of chronic rheumatic diseases [132, 133]. Thus, the $V d r$ gene itself can affect some chronic diseases and $1,25(\mathrm{OH})_{2} \mathrm{D}$-bound VDR can modulate transcription, leading to various cellular functions. Liver fibrosis, the result of excessive deposition of extracellular matrix components, is an irreversible wound-healing and tissue damaging/repair response that requires the activation of TGF $\beta / S M A D$ pathway in hepatic stellate cells (HSCs). Intriguingly, the VDR pathway is an endogenous inhibitor of TGF $\beta$ activation in the wound healing process [134]. VDR competes with SMAD3 at the 
profibrotic target gene promoters in hepatic stellate cells and thus inhibits fibrosis. Mice with $V d r-/-$ develop hepatic fibrosis spontaneously, suggesting that VDR is an endocrine antagonist to inhibit the wound-healing response in liver. In addition, calcipotriol, a VDR ligand, strongly suppresses inflammation and fibrosis in pancreatitis [135]. Interesting, VDR is a known target of Snail and is repressed by Snail during EMT [136], suggesting that Snail-mediated VDR repression provides a feed-back activation of TGF $\beta$ signaling and inflammatory response, facilitating fibrosis and EMT.

The tryptophan catabolic pathway plays an important role in tumor immunology. In 1998, Munn and Mellor showed that indoleamine 2,3-dioxygenase (IDO), a key enzyme that catalyzes the first step in tryptophan break down, is highly expressed in the placenta; this expression is required to prevent the mother's immune system to attack and reject the fetus [137]. The connection between tryptophan metabolism and immunosuppression is exciting, because it explains why expression of the father's genes, exposed in the fetus and normally marked for destruction by the mother's immune system, does not occur. IDO prevents the immune rejecting from happen and thus guarantees that women can nourish healthy fetuses to full-term. IDO has also been implicated in chronic viral infections and allergies, and in various autoimmune and inflammatory disorders in which immune control is disrupted [138]. Now, it appears that tumor cells hijack this metabolic pathway to evade the immune suppression. Early studies showed that many human tumors contain high level of IDO expression, and this often correlates with a poor clinical outcome. In addition, administration of an IDO inhibitor suppresses the growth of human lung cancer cells injected into mice $[139,140]$. Recent investigations indicate that kynurenine, a metabolite from the breakdown of tryptophan, is responsible for immune suppression and the pro-survival functions elicited by tumors [141]. Kynurenine generated by the tumor cells interacts to the aryl hydrocarbon receptor (AHR) in immune cells, causing suppression of effector $\mathrm{T}$ cells $\left(\mathrm{T}_{\text {eff }}\right)$ and inhibition of regulatory B cells $\left(\mathrm{B}_{\text {reg }}\right)$ and dendritic cells, and thus shuts down the immune response. These studies indicate that disruption of immune escape could restore immune attack; this notion was recognized as a priority task for the National Cancer Institute for developing the IDO inhibitor and Clinical trials began in 2007.

\section{Conclusions}

In the past several years, we have experienced a wealth of data in delineating the essential roles of chronic inflammation in EMT, ER stress and metabolism. New ideas and concepts are emerged and suggest that these essential cellular processes are intricately linked to each other. However, tumor cells hijack these cellular mechanisms for their own benefits in proliferation, invasion, metastasis, and drug resistance. Despite all these efforts, we are only starting appreciate the complexity of tumors and our limited understanding of the molecular processes by which tumor cells deployed under chronic inflammation. Therefore, future investigations to reveal the contribution of chronic inflammation, ER stress and metabolism in tumors will lead to a comprehensive understanding of oncogenesis and will provide us with effective therapeutic strategies for treating metastatic disease. 


\section{Acknowledgments}

We apologize to the many authors whose studies are important but could not be cited due to space limitation. Our study is supported by the grants from NIH (RO1s CA125454 and CA188118), DOD Breakthrough Award (BC140733P1), the Mary Kay Ash Foundation (to B.P. Zhou), and the National Natural Science Foundation of China (81402432 to J Liu).

\section{References}

1. Balkwill F, Mantovani A. Inflammation and cancer: back to Virchow? Lancet. 2001; 357:539-45. [PubMed: 11229684]

2. Dvorak HF. Tumors: wounds that do not heal. Similarities between tumor stroma generation and wound healing. N Engl J Med. 1986; 315:1650-9. [PubMed: 3537791]

3. Hussain SP, Harris CC. Inflammation and cancer: an ancient link with novel potentials. Int J Cancer. 2007; 121:2373-80. [PubMed: 17893866]

4. Coussens LM, Werb Z. Inflammation and cancer. Nature. 2002; 420:860-7. [PubMed: 12490959]

5. Ulrich CM, Bigler J, Potter JD. Non-steroidal anti-inflammatory drugs for cancer prevention: promise, perils and pharmacogenetics. Nat Rev Cancer. 2006; 6:130-40. [PubMed: 16491072]

6. Mantovani A, Allavena P, Sica A, Balkwill F. Cancer-related inflammation. Nature. 2008; 454:43644. [PubMed: 18650914]

7. Mantovani A. Cancer: Inflaming metastasis. Nature. 2009; 457:36-7. [PubMed: 19122629]

8. Hay ED. An overview of epithelio-mesenchymal transformation. Acta Anat (Basel). 1995; 154:820. [PubMed: 8714286]

9. Kalluri R, Neilson EG. Epithelial-mesenchymal transition and its implications for fibrosis. J Clin Invest. 2003; 112:1776-84. [PubMed: 14679171]

10. Zeisberg M, Neilson EG. Biomarkers for epithelial-mesenchymal transitions. J Clin Invest. 2009; 119:1429-37. [PubMed: 19487819]

11. Kalluri R, Weinberg RA. The basics of epithelial-mesenchymal transition. J Clin Invest. 2009; 119:1420-8. [PubMed: 19487818]

12. Kalluri R. EMT: when epithelial cells decide to become mesenchymal-like cells. J Clin Invest. 2009; 119:1417-9. [PubMed: 19487817]

13. Wu, Y., Zhou, BP. Epithelial-Mesenchymal transition in development and diseases. In: Bagley, Rebecca, G., editors. The Tumor Microenvironment Cancer Drug Discovery and Development. Springer; New York: 2010. p. 187-211.

14. Cowin P, Rowlands TM, Hatsell SJ. Cadherins and catenins in breast cancer. Curr Opin Cell Biol. 2005; 17:499-508. [PubMed: 16107313]

15. Junghans D, Haas IG, Kemler R. Mammalian cadherins and protocadherins: about cell death, synapses and processing. Curr Opin Cell Biol. 2005; 17:446-52. [PubMed: 16099637]

16. Davidson LA, Marsden M, Keller R, Desimone DW. Integrin alpha5beta1 and fibronectin regulate polarized cell protrusions required for Xenopus convergence and extension. Curr Biol. 2006; 16:833-44. [PubMed: 16682346]

17. White LR, Blanchette JB, Ren L, Awn A, Trpkov K, Muruve DA. The characterization of alpha5integrin expression on tubular epithelium during renal injury. Am J Physiol Renal Physiol. 2007; 292:F567-76. [PubMed: 17018844]

18. Qian F, Zhang ZC, Wu XF, Li YP, Xu Q. Interaction between integrin alpha(5) and fibronectin is required for metastasis of B16F10 melanoma cells. Biochem Biophys Res Commun. 2005; 333:1269-75. [PubMed: 15979576]

19. Hartwell KA, Muir B, Reinhardt F, Carpenter AE, Sgroi DC, Weinberg RA. The Spemann organizer gene, Goosecoid, promotes tumor metastasis. Proc Natl Acad Sci U S A. 2006; 103:18969-74. [PubMed: 17142318]

20. Nieto MA. The snail superfamily of zinc-finger transcription factors. Nat Rev Mol Cell Biol. 2002; 3:155-66. [PubMed: 11994736] 
21. Yang J, Mani SA, Donaher JL, Ramaswamy S, Itzykson RA, Come C, Savagner P, Gitelman I, Richardson A, Weinberg RA. Twist, a master regulator of morphogenesis, plays an essential role in tumor metastasis. Cell. 2004; 117:927-39. [PubMed: 15210113]

22. Alberga A, Boulay JL, Kempe E, Dennefeld C, Haenlin M. The snail gene required for mesoderm formation in Drosophila is expressed dynamically in derivatives of all three germ layers. Development. 1991; 111:983-92. [PubMed: 1879366]

23. Wu SY, McClay DR. The Snail repressor is required for PMC ingression in the sea urchin embryo. Development. 2007; 134:1061-70. [PubMed: 17287249]

24. Carver EA, Jiang R, Lan Y, Oram KF, Gridley T. The mouse snail gene encodes a key regulator of the epithelial-mesenchymal transition. Mol Cell Biol. 2001; 21:8184-8. [PubMed: 11689706]

25. Dong C, Wu Y, Wang Y, Wang C, Kang T, Rychahou PG, Chi YI, Evers BM, Zhou BP. Interaction with Suv39H1 is critical for Snail-mediated E-cadherin repression in breast cancer. Oncogene. 2012

26. Dong C, Wu Y, Yao J, Wang Y, Yu Y, Rychahou PG, Evers BM, Zhou BP. G9a interacts with Snail and is critical for Snail-mediated E-cadherin repression in human breast cancer. J Clin Invest. 2012; 122:1469-86. [PubMed: 22406531]

27. Lin Y, Wu Y, Li J, Dong C, Ye X, Chi YI, Evers BM, Zhou BP. The SNAG domain of Snail1 functions as a molecular hook for recruiting lysine-specific demethylase 1. EMBO J. 2010; 29:1803-16. [PubMed: 20389281]

28. Dong C, Yuan T, Wu Y, Wang Y, Fan TW, Miriyala S, Lin Y, Yao J, Shi J, Kang T, Lorkiewicz P, St Clair D, Hung MC, Evers BM, Zhou BP. Loss of FBP1 by Snail-mediated repression provides metabolic advantages in basal-like breast cancer. Cancer Cell. 2013; 23:316-31. [PubMed: 23453623]

29. Peinado H, Ballestar E, Esteller M, Cano A. Snail mediates E-cadherin repression by the recruitment of the Sin3A/histone deacetylase 1 (HDAC1)/HDAC2 complex. Mol Cell Biol. 2004; 24:306-19. [PubMed: 14673164]

30. Zhou BP, Deng J, Xia W, Xu J, Li YM, Gunduz M, Hung MC. Dual regulation of Snail by GSK-3beta-mediated phosphorylation in control of epithelial-mesenchymal transition. Nat Cell Biol. 2004; 6:931-40. [PubMed: 15448698]

31. Wu Y, Evers BM, Zhou BP. Small C-terminal domain phosphatase enhances snail activity through dephosphorylation. J Biol Chem. 2009; 284:640-8. [PubMed: 19004823]

32. Yang Z, Rayala S, Nguyen D, Vadlamudi RK, Chen S, Kumar R. Pak1 phosphorylation of snail, a master regulator of epithelial-to-mesenchyme transition, modulates snail's subcellular localization and functions. Cancer Res. 2005; 65:3179-84. [PubMed: 15833848]

33. Mani SA, Guo W, Liao MJ, Eaton EN, Ayyanan A, Zhou AY, Brooks M, Reinhard F, Zhang CC, Shipitsin M, Campbell LL, Polyak K, Brisken C, Yang J, Weinberg RA. The epithelialmesenchymal transition generates cells with properties of stem cells. Cell. 2008; 133:704-15. [PubMed: 18485877]

34. Vesuna F, Lisok A, Kimble B, Raman V. Twist modulates breast cancer stem cells by transcriptional regulation of CD24 expression. Neoplasia. 2009; 11:1318-28. [PubMed: 20019840]

35. Li J, Zhou BP. Activation of beta-catenin and Akt pathways by Twist are critical for the maintenance of EMT associated cancer stem cell-like characters. BMC Cancer. 2011; 11:49. [PubMed: 21284870]

36. Ma L, Teruya-Feldstein J, Weinberg RA. Tumour invasion and metastasis initiated by microRNA-10b in breast cancer. Nature. 2007; 449:682-8. [PubMed: 17898713]

37. Eckert MA, Lwin TM, Chang AT, Kim J, Danis E, Ohno-Machado L, Yang J. Twist1-induced invadopodia formation promotes tumor metastasis. Cancer Cell. 2011; 19:372-86. [PubMed: 21397860]

38. Maestro R, Dei Tos AP, Hamamori Y, Krasnokutsky S, Sartorelli V, Kedes L, Doglioni C, Beach DH, Hannon GJ. Twist is a potential oncogene that inhibits apoptosis. Genes Dev. 1999; 13:220717. [PubMed: 10485844] 
39. Valsesia-Wittmann S, Magdeleine M, Dupasquier S, Garin E, Jallas AC, Combaret V, Krause A, Leissner P, Puisieux A. Oncogenic cooperation between H-Twist and N-Myc overrides failsafe programs in cancer cells. Cancer Cell. 2004; 6:625-30. [PubMed: 15607966]

40. Ansieau S, Bastid J, Doreau A, Morel AP, Bouchet BP, Thomas C, Fauvet F, Puisieux I, Doglioni C, Piccinin S, Maestro R, Voeltzel T, Selmi A, Valsesia-Wittmann S, Caron de Fromentel C, Puisieux A. Induction of EMT by twist proteins as a collateral effect of tumor-promoting inactivation of premature senescence. Cancer Cell. 2008; 14:79-89. [PubMed: 18598946]

41. Li QQ, Xu JD, Wang WJ, Cao XX, Chen Q, Tang F, Chen ZQ, Liu XP, Xu ZD. Twist1-mediated adriamycin-induced epithelial-mesenchymal transition relates to multidrug resistance and invasive potential in breast cancer cells. Clin Cancer Res. 2009; 15:2657-65. [PubMed: 19336515]

42. Cheng GZ, Chan J, Wang Q, Zhang W, Sun CD, Wang LH. Twist transcriptionally up-regulates AKT2 in breast cancer cells leading to increased migration, invasion, and resistance to paclitaxel. Cancer Res. 2007; 67:1979-87. [PubMed: 17332325]

43. Firulli BA, Krawchuk D, Centonze VE, Vargesson N, Virshup DM, Conway SJ, Cserjesi P, Laufer E, Firulli AB. Altered Twist1 and Hand 2 dimerization is associated with Saethre-Chotzen syndrome and limb abnormalities. Nat Genet. 2005; 37:373-81. [PubMed: 15735646]

44. Vichalkovski A, Gresko E, Hess D, Restuccia DF, Hemmings BA. PKB/AKT phosphorylation of the transcription factor Twist-1 at Ser42 inhibits p53 activity in response to DNA damage. Oncogene. 2010; 29:3554-65. [PubMed: 20400976]

45. Xue G, Restuccia DF, Lan Q, Hynx D, Dirnhofer S, Hess D, Ruegg C, Hemmings BA. Akt/PKBmediated phosphorylation of Twist1 promotes tumor metastasis via mediating cross-talk between PI3K/Akt and TGF-beta signaling axes. Cancer Discov. 2012; 2:248-59. [PubMed: 22585995]

46. Hong J, Zhou J, Fu J, He T, Qin J, Wang L, Liao L, Xu J. Phosphorylation of serine 68 of Twist1 by MAPKs stabilizes Twist 1 protein and promotes breast cancer cell invasiveness. Cancer Res. 2011; 71:3980-90. [PubMed: 21502402]

47. Su YW, Xie TX, Sano D, Myers JN. IL-6 stabilizes Twist and enhances tumor cell motility in head and neck cancer cells through activation of casein kinase 2. PLoS One. 2011; 6:e19412. [PubMed: 21559372]

48. Lander R, Nasr T, Ochoa SD, Nordin K, Prasad MS, Labonne C. Interactions between Twist and other core epithelial-mesenchymal transition factors are controlled by GSK3-mediated phosphorylation. Nat Commun. 2013; 4:1542. [PubMed: 23443570]

49. Kress W, Schropp C, Lieb G, Petersen B, Busse-Ratzka M, Kunz J, Reinhart E, Schafer WD, Sold J, Hoppe F, Pahnke J, Trusen A, Sorensen N, Krauss J, Collmann H. Saethre-Chotzen syndrome caused by TWIST 1 gene mutations: functional differentiation from Muenke coronal synostosis syndrome. Eur J Hum Genet. 2006; 14:39-48. [PubMed: 16251895]

50. Piccinin S, Tonin E, Sessa S, Demontis S, Rossi S, Pecciarini L, Zanatta L, Pivetta F, Grizzo A, Sonego M, Rosano C, Dei Tos AP, Doglioni C, Maestro R. A"twist box" code of p53 inactivation: twist box: p53 interaction promotes p53 degradation. Cancer Cell. 2012; 22:404-15. [PubMed: 22975381]

51. Gu S, Boyer TG, Naski MC. Basic helix-loop-helix transcription factor Twist1 inhibits transactivator function of master chondrogenic regulator Sox9. J Biol Chem. 2012; 287:21082-92. [PubMed: 22532563]

52. Qin Q, Xu Y, He T, Qin C, Xu J. Normal and disease-related biological functions of Twist1 and underlying molecular mechanisms. Cell Res. 2012; 22:90-106. [PubMed: 21876555]

53. Shi J, Wang Y, Zeng L, Wu Y, Deng J, Zhang Q, Lin Y, Li J, Kang T, Tao M, Rusinova E, Zhang G, Wang C, Zhu H, Yao J, Zeng YX, Evers BM, Zhou MM, Zhou BP. Disrupting the Interaction of BRD4 with Diacetylated Twist Suppresses Tumorigenesis in Basal-like Breast Cancer. Cancer Cell. 2014; 25:210-25. [PubMed: 24525235]

54. Franci C, Takkunen M, Dave N, Alameda F, Gomez S, Rodriguez R, Escriva M, Montserrat-Sentis B, Baro T, Garrido M, Bonilla F, Virtanen I, Garcia de Herreros A. Expression of Snail protein in tumor-stroma interface. Oncogene. 2006; 25:5134-44. [PubMed: 16568079]

55. Christofori G. New signals from the invasive front. Nature. 2006; 441:444-50. [PubMed: 16724056] 
56. Ohlund D, Elyada E, Tuveson D. Fibroblast heterogeneity in the cancer wound. J Exp Med. 2014; 211:1503-23. [PubMed: 25071162]

57. Chang HY, Sneddon JB, Alizadeh AA, Sood R, West RB, Montgomery K, Chi JT, van de Rijn M, Botstein D, Brown PO. Gene expression signature of fibroblast serum response predicts human cancer progression: similarities between tumors and wounds. PLoS Biol. 2004; 2:E7. [PubMed: 14737219]

58. Joyce JA, Pollard JW. Microenvironmental regulation of metastasis. Nat Rev Cancer. 2009; 9:239_ 52. [PubMed: 19279573]

59. Condeelis J, Pollard JW. Macrophages: obligate partners for tumor cell migration, invasion, and metastasis. Cell. 2006; 124:263-6. [PubMed: 16439202]

60. Pollard JW. Tumour-educated macrophages promote tumour progression and metastasis. Nat Rev Cancer. 2004; 4:71-8. [PubMed: 14708027]

61. Dotto GP. Multifocal epithelial tumors and field cancerization: stroma as a primary determinant. J Clin Invest. 2014; 124:1446-53. [PubMed: 24691479]

62. Tripathi M, Billet S, Bhowmick NA. Understanding the role of stromal fibroblasts in cancer progression. Cell Adh Migr. 2012; 6:231-5. [PubMed: 22568983]

63. Orimo A, Gupta PB, Sgroi DC, Arenzana-Seisdedos F, Delaunay T, Naeem R, Carey VJ, Richardson AL, Weinberg RA. Stromal fibroblasts present in invasive human breast carcinomas promote tumor growth and angiogenesis through elevated SDF-1/CXCL12 secretion. Cell. 2005; 121:335-48. [PubMed: 15882617]

64. Wang J, Ying G, Wang J, Jung Y, Lu J, Zhu J, Pienta KJ, Taichman RS. Characterization of phosphoglycerate kinase-1 expression of stromal cells derived from tumor microenvironment in prostate cancer progression. Cancer Res. 2010; 70:471-80. [PubMed: 20068185]

65. Zhang D, Wang Y, Shi Z, Liu J, Sun P, Hou X, Zhang J, Zhao S, Zhou BP, Mi J. Metabolic Reprogramming of Cancer-Associated Fibroblasts by IDH3alpha Downregulation. Cell Rep. 2015; 10:1335-48. [PubMed: 25732824]

66. Almand B, Clark JI, Nikitina E, van Beynen J, English NR, Knight SC, Carbone DP, Gabrilovich DI. Increased production of immature myeloid cells in cancer patients: a mechanism of immunosuppression in cancer. J Immunol. 2001; 166:678-89. [PubMed: 11123353]

67. Young MR, Lathers DM. Myeloid progenitor cells mediate immune suppression in patients with head and neck cancers. Int J Immunopharmacol. 1999; 21:241-52. [PubMed: 10408632]

68. Gabrilovich DI, Nagaraj S. Myeloid-derived suppressor cells as regulators of the immune system. Nat Rev Immunol. 2009; 9:162-74. [PubMed: 19197294]

69. Sinha P, Clements VK, Bunt SK, Albelda SM, Ostrand-Rosenberg S. Cross-talk between myeloidderived suppressor cells and macrophages subverts tumor immunity toward a type 2 response. J Immunol. 2007; 179:977-83. [PubMed: 17617589]

70. Yang L, Huang J, Ren X, Gorska AE, Chytil A, Aakre M, Carbone DP, Matrisian LM, Richmond A, Lin PC, Moses HL. Abrogation of TGF beta signaling in mammary carcinomas recruits Gr-1+CD11b+ myeloid cells that promote metastasis. Cancer Cell. 2008; 13:23-35. [PubMed: 18167337]

71. Diaz-Montero CM, Salem ML, Nishimura MI, Garrett-Mayer E, Cole DJ, Montero AJ. Increased circulating myeloid-derived suppressor cells correlate with clinical cancer stage, metastatic tumor burden, and doxorubicin-cyclophosphamide chemotherapy. Cancer Immunol Immunother. 2009; 58:49-59. [PubMed: 18446337]

72. Creighton CJ, Li X, Landis M, Dixon JM, Neumeister VM, Sjolund A, Rimm DL, Wong H, Rodriguez A, Herschkowitz JI, Fan C, Zhang X, He X, Pavlick A, Gutierrez MC, Renshaw L, Larionov AA, Faratian D, Hilsenbeck SG, Perou CM, Lewis MT, Rosen JM, Chang JC. Residual breast cancers after conventional therapy display mesenchymal as well as tumor-initiating features. Proc Natl Acad Sci U S A. 2009

73. Li X, Lewis MT, Huang J, Gutierrez C, Osborne CK, Wu MF, Hilsenbeck SG, Pavlick A, Zhang X, Chamness GC, Wong H, Rosen J, Chang JC. Intrinsic resistance of tumorigenic breast cancer cells to chemotherapy. J Natl Cancer Inst. 2008; 100:672-9. [PubMed: 18445819] 
74. Moody SE, Perez D, Pan TC, Sarkisian CJ, Portocarrero CP, Sterner CJ, Notorfrancesco KL, Cardiff RD, Chodosh LA. The transcriptional repressor Snail promotes mammary tumor recurrence. Cancer Cell. 2005; 8:197-209. [PubMed: 16169465]

75. Aktas B, Tewes M, Fehm T, Hauch S, Kimmig R, Kasimir-Bauer S. Stem cell and epithelialmesenchymal transition markers are frequently overexpressed in circulating tumor cells of metastatic breast cancer patients. Breast Cancer Res. 2009; 11:R46. [PubMed: 19589136]

76. Armstrong AJ, Marengo MS, Oltean S, Kemeny G, Bitting RL, Turnbull JD, Herold CI, Marcom PK, George DJ, Garcia-Blanco MA. Circulating tumor cells from patients with advanced prostate and breast cancer display both epithelial and mesenchymal markers. Mol Cancer Res. 2011; 9:997-1007. [PubMed: 21665936]

77. Bonnomet A, Brysse A, Tachsidis A, Waltham M, Thompson EW, Polette M, Gilles C. Epithelialto-mesenchymal transitions and circulating tumor cells. J Mammary Gland Biol Neoplasia. 2010; 15:261-73. [PubMed: 20449641]

78. Kallergi G, Papadaki MA, Politaki E, Mavroudis D, Georgoulias V, Agelaki S. Epithelial to mesenchymal transition markers expressed in circulating tumour cells of early and metastatic breast cancer patients. Breast Cancer Res. 2011; 13:R59. [PubMed: 21663619]

79. Kasimir-Bauer S, Hoffmann O, Wallwiener D, Kimmig R, Fehm T. Expression of stem cell and epithelial-mesenchymal transition markers in primary breast cancer patients with circulating tumor cells. Breast Cancer Res. 2012; 14:R15. [PubMed: 22264265]

80. Lu J, Fan T, Zhao Q, Zeng W, Zaslavsky E, Chen JJ, Frohman MA, Golightly MG, Madajewicz S, Chen WT. Isolation of circulating epithelial and tumor progenitor cells with an invasive phenotype from breast cancer patients. Int J Cancer. 2010; 126:669-83. [PubMed: 19662651]

81. Mego M, Mani SA, Lee BN, Li C, Evans KW, Cohen EN, Gao H, Jackson SA, Giordano A, Hortobagyi GN, Cristofanilli M, Lucci A, Reuben JM. Expression of epithelial-mesenchymal transition-inducing transcription factors in primary breast cancer: The effect of neoadjuvant therapy. Int J Cancer. 2012; 130:808-16. [PubMed: 21387303]

82. Raimondi C, Gradilone A, Naso G, Vincenzi B, Petracca A, Nicolazzo C, Palazzo A, Saltarelli R, Spremberg F, Cortesi E, Gazzaniga P. Epithelial-mesenchymal transition and stemness features in circulating tumor cells from breast cancer patients. Breast Cancer Res Treat. 2011; 130:449-55. [PubMed: 21298334]

83. Yu M, Bardia A, Wittner BS, Stott SL, Smas ME, Ting DT, Isakoff SJ, Ciciliano JC, Wells MN, Shah AM, Concannon KF, Donaldson MC, Sequist LV, Brachtel E, Sgroi D, Baselga J, Ramaswamy S, Toner M, Haber DA, Maheswaran S. Circulating breast tumor cells exhibit dynamic changes in epithelial and mesenchymal composition. Science. 2013; 339:580-4. [PubMed: 23372014]

84. Badve S, Dabbs DJ, Schnitt SJ, Baehner FL, Decker T, Eusebi V, Fox SB, Ichihara S, Jacquemier J, Lakhani SR, Palacios J, Rakha EA, Richardson AL, Schmitt FC, Tan PH, Tse GM, Weigelt B, Ellis IO, Reis-Filho JS. Basal-like and triple-negative breast cancers: a critical review with an emphasis on the implications for pathologists and oncologists. Mod Pathol. 2011; 24:157-67. [PubMed: 21076464]

85. Fadare O, Tavassoli FA. Clinical and pathologic aspects of basal-like breast cancers. Nat Clin Pract Oncol. 2008; 5:149-59. [PubMed: 18212769]

86. Korsching E, Jeffrey SS, Meinerz W, Decker T, Boecker W, Buerger H. Basal carcinoma of the breast revisited: an old entity with new interpretations. J Clin Pathol. 2008; 61:553-60. [PubMed: 18326009]

87. Kreike B, van Kouwenhove M, Horlings H, Weigelt B, Peterse H, Bartelink H, van de Vijver MJ. Gene expression profiling and histopathological characterization of triple-negative/basal-like breast carcinomas. Breast Cancer Res. 2007; 9:R65. [PubMed: 17910759]

88. Rakha EA, Reis-Filho JS, Ellis IO. Basal-like breast cancer: a critical review. J Clin Oncol. 2008; 26:2568-81. [PubMed: 18487574]

89. Mani SA, Yang J, Brooks M, Schwaninger G, Zhou A, Miura N, Kutok JL, Hartwell K, Richardson AL, Weinberg RA. Mesenchyme Forkhead 1 (FOXC2) plays a key role in metastasis and is associated with aggressive basal-like breast cancers. Proc Natl Acad Sci U S A. 2007; 104:1006974. [PubMed: 17537911] 
90. Hermann PC, Huber SL, Herrler T, Aicher A, Ellwart JW, Guba M, Bruns CJ, Heeschen C. Distinct populations of cancer stem cells determine tumor growth and metastatic activity in human pancreatic cancer. Cell Stem Cell. 2007; 1:313-23. [PubMed: 18371365]

91. Staller P, Sulitkova J, Lisztwan J, Moch H, Oakeley EJ, Krek W. Chemokine receptor CXCR4 downregulated by von Hippel-Lindau tumour suppressor pVHL. Nature. 2003; 425:307-11. [PubMed: 13679920]

92. Krishnamachary B, Berg-Dixon S, Kelly B, Agani F, Feldser D, Ferreira G, Iyer N, LaRusch J, Pak B, Taghavi P, Semenza GL. Regulation of colon carcinoma cell invasion by hypoxia-inducible factor 1. Cancer Res. 2003; 63:1138-43. [PubMed: 12615733]

93. Hotz B, Arndt M, Dullat S, Bhargava S, Buhr HJ, Hotz HG. Epithelial to mesenchymal transition: expression of the regulators snail, slug, and twist in pancreatic cancer. Clin Cancer Res. 2007; 13:4769-76. [PubMed: 17699854]

94. Imai T, Horiuchi A, Wang C, Oka K, Ohira S, Nikaido T, Konishi I. Hypoxia attenuates the expression of E-cadherin via up-regulation of SNAIL in ovarian carcinoma cells. Am J Pathol. 2003; 163:1437-47. [PubMed: 14507651]

95. Davidson NE, Sukumar S. Of Snail, mice, and women. Cancer Cell. 2005; 8:173-4. [PubMed: 16169460]

96. Yang MH, Wu MZ, Chiou SH, Chen PM, Chang SY, Liu CJ, Teng SC, Wu KJ. Direct regulation of TWIST by HIF-1alpha promotes metastasis. Nat Cell Biol. 2008; 10:295-305. [PubMed: 18297062]

97. Lunt SJ, Chaudary N, Hill RP. The tumor microenvironment and metastatic disease. Clin Exp Metastasis. 2009; 26:19-34. [PubMed: 18543068]

98. Peinado H, Del Carmen Iglesias-de la Cruz M, Olmeda D, Csiszar K, Fong KS, Vega S, Nieto MA, Cano A, Portillo F. A molecular role for lysyl oxidase-like 2 enzyme in snail regulation and tumor progression. Embo J. 2005; 24:3446-58. [PubMed: 16096638]

99. Peinado H, Portillo F, Cano A. Switching on-off Snail: LOXL2 versus GSK3beta. Cell Cycle. 2005; 4:1749-52. [PubMed: 16294032]

100. Glimcher LH. XBP1: the last two decades. Ann Rheum Dis. 2010; 69(Suppl 1):i67-71. [PubMed: 19995749]

101. Hetz C, Martinon F, Rodriguez D, Glimcher LH. The unfolded protein response: integrating stress signals through the stress sensor IRE1alpha. Physiol Rev. 2011; 91:1219-43. [PubMed: 22013210]

102. Kaser A, Martinez-Naves E, Blumberg RS. Endoplasmic reticulum stress: implications for inflammatory bowel disease pathogenesis. Curr Opin Gastroenterol. 2010; 26:318-26. [PubMed: 20495455]

103. Walter P, Ron D. The unfolded protein response: from stress pathway to homeostatic regulation. Science. 2011; 334:1081-6. [PubMed: 22116877]

104. Acosta-Alvear D, Zhou Y, Blais A, Tsikitis M, Lents NH, Arias C, Lennon CJ, Kluger Y, Dynlacht BD. XBP1 controls diverse cell type- and condition-specific transcriptional regulatory networks. Mol Cell. 2007; 27:53-66. [PubMed: 17612490]

105. Medzhitov R, Schneider DS, Soares MP. Disease tolerance as a defense strategy. Science. 2012; 335:936-41. [PubMed: 22363001]

106. Ma A. Unresolved ER Stress Inflames the Intestine. Cell. 2008; 134:724-5. [PubMed: 18775305]

107. Hu P, Han Z, Couvillon AD, Kaufman RJ, Exton JH. Autocrine tumor necrosis factor alpha links endoplasmic reticulum stress to the membrane death receptor pathway through IRE1alphamediated NF-kappaB activation and down-regulation of TRAF2 expression. Mol Cell Biol. 2006; 26:3071-84. [PubMed: 16581782]

108. Kaneko M, Niinuma Y, Nomura Y. Activation signal of nuclear factor-kappa B in response to endoplasmic reticulum stress is transduced via IRE1 and tumor necrosis factor receptorassociated factor 2. Biol Pharm Bull. 2003; 26:931-5. [PubMed: 12843613]

109. Kaser A, Lee AH, Franke A, Glickman JN, Zeissig S, Tilg H, Nieuwenhuis EE, Higgins DE, Schreiber S, Glimcher LH, Blumberg RS. XBP1 links ER stress to intestinal inflammation and confers genetic risk for human inflammatory bowel disease. Cell. 2008; 134:743-56. [PubMed: 18775308] 
110. Urano F, Wang X, Bertolotti A, Zhang Y, Chung P, Harding HP, Ron D. Coupling of stress in the ER to activation of JNK protein kinases by transmembrane protein kinase IRE1. Science. 2000; 287:664-6. [PubMed: 10650002]

111. Kaser A, Blumberg RS. Survive an innate immune response through XBP1. Cell Res. 2010; 20:506-7. [PubMed: 20436510]

112. Richardson CE, Kooistra T, Kim DH. An essential role for XBP-1 in host protection against immune activation in C. elegans. Nature. 2010; 463:1092-5. [PubMed: 20182512]

113. Hamilton MJ, Stevens RL. Stress in the ER leads to inflammatory bowel disease. Inflamm Bowel Dis. 2009; 15:1765-6. [PubMed: 19408317]

114. Bates GJ, Fox SB, Han C, Leek RD, Garcia JF, Harris AL, Banham AH. Quantification of regulatory $\mathrm{T}$ cells enables the identification of high-risk breast cancer patients and those at risk of late relapse. J Clin Oncol. 2006; 24:5373-80. [PubMed: 17135638]

115. Bohling SD, Allison KH. Immunosuppressive regulatory T cells are associated with aggressive breast cancer phenotypes: a potential therapeutic target. Mod Pathol. 2008; 21:1527-32. [PubMed: 18820666]

116. Denardo DG, Brennan DJ, Rexhepaj E, Ruffell B, Shiao SL, Madden SF, Gallagher WM, Wadhwani N, Keil SD, Junaid SA, Rugo HS, Hwang ES, Jirstrom K, West BL, Coussens LM. Leukocyte Complexity Predicts Breast Cancer Survival and Functionally Regulates Response to Chemotherapy. Cancer Discov. 2011; 1:54-67. [PubMed: 22039576]

117. Livasy CA, Karaca G, Nanda R, Tretiakova MS, Olopade OI, Moore DT, Perou CM. Phenotypic evaluation of the basal-like subtype of invasive breast carcinoma. Mod Pathol. 2006; 19:264-71. [PubMed: 16341146]

118. Biswas DK, Dai SC, Cruz A, Weiser B, Graner E, Pardee AB. The nuclear factor kappa B (NFkappa B): a potential therapeutic target for estrogen receptor negative breast cancers. Proc Natl Acad Sci U S A. 2001; 98:10386-91. [PubMed: 11517301]

119. Biswas DK, Shi Q, Baily S, Strickland I, Ghosh S, Pardee AB, Iglehart JD. NF-kappa B activation in human breast cancer specimens and its role in cell proliferation and apoptosis. Proc Natl Acad Sci U S A. 2004; 101:10137-42. [PubMed: 15220474]

120. Nakshatri H, Bhat-Nakshatri P, Martin DA, Goulet RJ Jr, Sledge GW Jr. Constitutive activation of NF-kappaB during progression of breast cancer to hormone-independent growth. Mol Cell Biol. 1997; 17:3629-39. [PubMed: 9199297]

121. Wang X, Belguise K, Kersual N, Kirsch KH, Mineva ND, Galtier F, Chalbos D, Sonenshein GE. Oestrogen signalling inhibits invasive phenotype by repressing RelB and its target BCL2. Nat Cell Biol. 2007; 9:470-8. [PubMed: 17369819]

122. Yamaguchi N, Ito T, Azuma S, Ito E, Honma R, Yanagisawa Y, Nishikawa A, Kawamura M, Imai J, Watanabe S, Semba K, Inoue J. Constitutive activation of nuclear factor-kappaB is preferentially involved in the proliferation of basal-like subtype breast cancer cell lines. Cancer Sci. 2009; 100:1668-74. [PubMed: 19538528]

123. Kolattukudy PE, Niu J. Inflammation, endoplasmic reticulum stress, autophagy, and the monocyte chemoattractant protein-1/CCR2 pathway. Circ Res. 2012; 110:174-89. [PubMed: 22223213]

124. Melgarejo E, Medina MA, Sanchez-Jimenez F, Urdiales JL. Monocyte chemoattractant protein-1: a key mediator in inflammatory processes. Int J Biochem Cell Biol. 2009; 41:998-1001. [PubMed: 18761421]

125. Qian BZ, Li J, Zhang H, Kitamura T, Zhang J, Campion LR, Kaiser EA, Snyder LA, Pollard JW. CCL2 recruits inflammatory monocytes to facilitate breast-tumour metastasis. Nature. 2011; 475:222-5. [PubMed: 21654748]

126. Scheede-Bergdahl C, Watt HL, Trutschnigg B, Kilgour RD, Haggarty A, Lucar E, Vigano A. Is IL-6 the best pro-inflammatory biomarker of clinical outcomes of cancer cachexia? Clin Nutr. 2012; 31:85-8. [PubMed: 21855185]

127. Strassmann G, Fong M, Kenney JS, Jacob CO. Evidence for the involvement of interleukin 6 in experimental cancer cachexia. J Clin Invest. 1992; 89:1681-4. [PubMed: 1569207]

128. Fearon KC, Moses AG. Cancer cachexia. Int J Cardiol. 2002; 85:73-81. [PubMed: 12163211]

129. Arnson Y, Amital H, Shoenfeld Y. Vitamin D and autoimmunity: new aetiological and therapeutic considerations. Ann Rheum Dis. 2007; 66:1137-42. [PubMed: 17557889] 
130. Haussler MR, Haussler CA, Whitfield GK, Hsieh JC, Thompson PD, Barthel TK, Bartik L, Egan JB, Wu Y, Kubicek JL, Lowmiller CL, Moffet EW, Forster RE, Jurutka PW. The nuclear vitamin D receptor controls the expression of genes encoding factors which feed the "Fountain of Youth" to mediate healthful aging. J Steroid Biochem Mol Biol. 2010; 121:88-97. [PubMed: 20227497]

131. Pludowski P, Holick MF, Pilz S, Wagner CL, Hollis BW, Grant WB, Shoenfeld Y, Lerchbaum E, Llewellyn DJ, Kienreich K, Soni M. Vitamin D effects on musculoskeletal health, immunity, autoimmunity, cardiovascular disease, cancer, fertility, pregnancy, dementia and mortality-a review of recent evidence. Autoimmun Rev. 2013; 12:976-89. [PubMed: 23542507]

132. Maalej A, Petit-Teixeira E, Michou L, Rebai A, Cornelis F, Ayadi H. Association study of VDR gene with rheumatoid arthritis in the French population. Genes Immun. 2005; 6:707-11. [PubMed: 16151416]

133. Ranganathan P. Genetics of bone loss in rheumatoid arthritis--role of vitamin D receptor polymorphisms. Rheumatology (Oxford). 2009; 48:342-6. [PubMed: 19151030]

134. Ding N, Yu RT, Subramaniam N, Sherman MH, Wilson C, Rao R, Leblanc M, Coulter S, He M, Scott C, Lau SL, Atkins AR, Barish GD, Gunton JE, Liddle C, Downes M, Evans RM. A vitamin D receptor/SMAD genomic circuit gates hepatic fibrotic response. Cell. 2013; 153:601-13. [PubMed: 23622244]

135. Sherman MH, Yu RT, Engle DD, Ding N, Atkins AR, Tiriac H, Collisson EA, Connor F, Van Dyke T, Kozlov S, Martin P, Tseng TW, Dawson DW, Donahue TR, Masamune A, Shimosegawa T, Apte MV, Wilson JS, Ng B, Lau SL, Gunton JE, Wahl GM, Hunter T, Drebin JA, O'Dwyer PJ, Liddle C, Tuveson DA, Downes M, Evans RM. Vitamin d receptor-mediated stromal reprogramming suppresses pancreatitis and enhances pancreatic cancer therapy. Cell. 2014; 159:80-93. [PubMed: 25259922]

136. Palmer HG, Larriba MJ, Garcia JM, Ordonez-Moran P, Pena C, Peiro S, Puig I, Rodriguez R, de la Fuente R, Bernad A, Pollan M, Bonilla F, Gamallo C, de Herreros AG, Munoz A. The transcription factor SNAIL represses vitamin D receptor expression and responsiveness in human colon cancer. Nat Med. 2004; 10:917-9. [PubMed: 15322538]

137. Munn DH, Zhou M, Attwood JT, Bondarev I, Conway SJ, Marshall B, Brown C, Mellor AL. Prevention of allogeneic fetal rejection by tryptophan catabolism. Science. 1998; 281:1191-3. [PubMed: 9712583]

138. Katz JB, Muller AJ, Prendergast GC. Indoleamine 2,3-dioxygenase in T-cell tolerance and tumoral immune escape. Immunol Rev. 2008; 222:206-21. [PubMed: 18364004]

139. Friberg M, Jennings R, Alsarraj M, Dessureault S, Cantor A, Extermann M, Mellor AL, Munn $\mathrm{DH}$, Antonia SJ. Indoleamine 2,3-dioxygenase contributes to tumor cell evasion of T cellmediated rejection. Int J Cancer. 2002; 101:151-5. [PubMed: 12209992]

140. Uyttenhove C, Pilotte L, Theate I, Stroobant V, Colau D, Parmentier N, Boon T, Van den Eynde BJ. Evidence for a tumoral immune resistance mechanism based on tryptophan degradation by indoleamine 2,3-dioxygenase. Nat Med. 2003; 9:1269-74. [PubMed: 14502282]

141. Opitz CA, Litzenburger UM, Sahm F, Ott M, Tritschler I, Trump S, Schumacher T, Jestaedt L, Schrenk D, Weller M, Jugold M, Guillemin GJ, Miller CL, Lutz C, Radlwimmer B, Lehmann I, von Deimling A, Wick W, Platten M. An endogenous tumour-promoting ligand of the human aryl hydrocarbon receptor. Nature. 2011; 478:197-203. [PubMed: 21976023] 


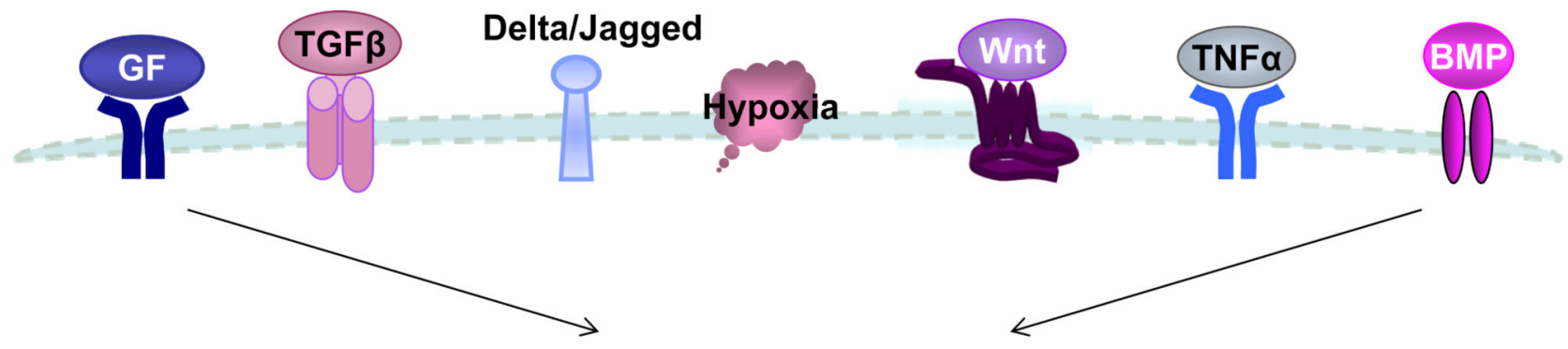

\section{Snail Twist}

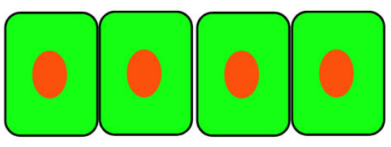

Epithelial cells

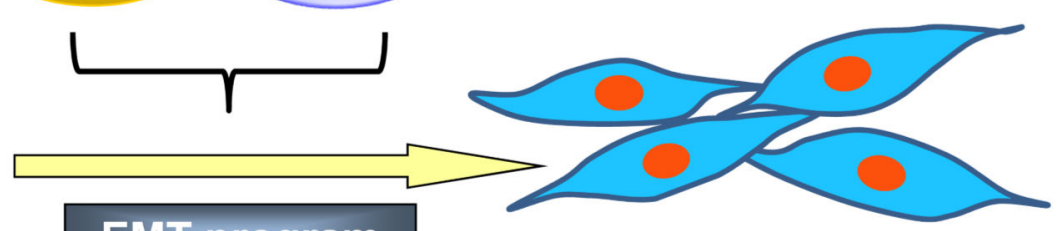

EMT program

\section{Mesenchymal cells}

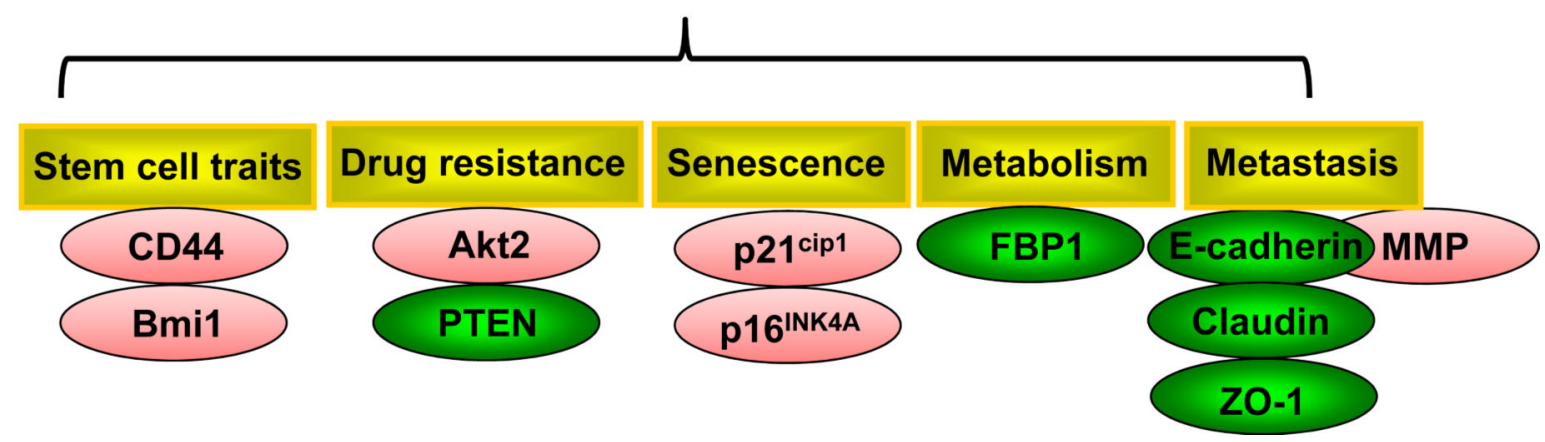

Figure 1. Schematic diagram of the signaling pathways associated with Snail and Twist induced EMT

An integrated and complex signaling network, including RTKs, TGF- $\beta$, Notch, Wnt, TNF$a$, and BMPs signaling pathways, activate Snail and Twist, resulting in the EMT induction. Snail functions as a transcriptional repressor to suppress genes that prevent cell migration and growth (such as E-cadherin and FBP1); whereas Twist acts as a transcriptional activator to induce genes that favor cell migration and proliferation (Wnt5A) in an analogy of a moving car that has disabled brakes and an accelerating engine. 